\title{
HUBUNGAN PERTAMBAHAN BERAT BADAN SELAMA KEHAMILAN DENGAN BERAT LAHIR BAYI DI KECAMATAN SUKARAJA KABUPATEN BOGOR TAHUN 2001 - 2003
}

\author{
Elmy Rindang T. ${ }^{1} ;$ Fatmah $^{2}$ dan Anies Irawati ${ }^{3}$ \\ 'Direktorat Gizi Masyarakat, Departemen Kesehatan RI \\ ${ }^{2}$ Departemen Gizi, Fakultas Kesehatan Masyarakat, Universitas Indonesia \\ ${ }^{3}$ Pusat Penelitian dan Pengembangan Gizi dan Makanan, Depkes RI
}

\section{ABSTRACT \\ THE RELATIONSHIP BETWEEN WEIGHT GAIN DURING PREGNANCY AND BIRTH WEIGHT IN SUKARAJA SUBDISTRICT, BOGOR IN 2001 - 2003}

Maternal body weight gain during pregnancy is important for women suffering from wasting when pregnancy started. Many studies in Indonesia show that low maternal weight gain during pregnancy (less than $10 \mathrm{~kg}$ ) and high prevalence of pregnant women who had cronic energy deficiency $(27.6 \%)$ are still problem. The objective of the study is to determine relationship between of maternal weight gain during pregnancy and low birth weight (2500-2999 gram) and its related factors. The study desain was cross-sectional, involving 270 pregnant women, at early stages (12 weeks) who delivered a normal body weight and full term babies (> 37 weeks). Data analysis was done using logistic regression. The result showed that the babies with low birth weight (2500-2999 gram) was 47.8 persen with the average weight of $3015 \mathrm{gram}$. The average of maternal weight gain during pregnancy was $9.098 \mathrm{~kg}$ and those who gained less than $9 \mathrm{~kg}$ during pregnancy was 48.9 persen. A significant relationship was found birth weight gain during pregnancy $(p=0.000, \mathrm{OR} 7.28,95 \% \mathrm{Cl} ; 4.25-12.46)$, and energy intake $((p=0.000$, OR $5.15,95 \%$ $\mathrm{Cl}$; 2.976-8.913). Multivariate analysis shows that the interaction between energy intake and weight gain during pregnancy is statistically significant ( $p=0.000$, OR $5.8,95 \% \mathrm{Cl} ; 1.574-21.536$ ). In conclusion, women who had gain weight at least $9 \mathrm{~kg}$ during pregnancy and energy intake more than 70 persen RDA might baby between with birth weight of less than 3000 gram. It is important especially to those who get pregnant suffering from wasting.

Keywords: weight gain, pregnancy, birth weight

\section{PENDAHULUAN}

$\mathrm{K}$ ejadian bayi dengan berat lahir rendah (BBLR) yakni kurang dari 2,5 kilogram merupakan indikasi adanya gangguan kesehatan dan gizi pada ibu ketika hamil. Dibandingkan bayi berat lahir normal, bayi dengan BBLR menghadapi risiko kematian lebih tinggi pada bulan pertama kehidupannya. BBLR juga dapat berpengaruh pada gangguan pertumbuhan fisik dan mental anak. Meskipun demikian berat lahir bayi antara 2500-2999 gram yang selanjutnya dikatakan sebagai bayi berat lahir kurang ${ }^{1)}$ bukan bebas dari risiko. Berat lahir bayi 2500-2999 gram masih menunjukkan risiko yang tinggi untuk kematian dan morbiditas seperti Infeski Saluran Pernafasan Akut (ISPA), diare, keterlambatan pertumbuhan dan perkembangan. Dalam kelompok ini masih terdapat bayi dengan ukuran kecil untuk massa kehamilan yang disebut Intra Uterine Growth Retardation (IUGR). 
Studi kolaborasi melibatkan penelitian dari 22 negara oleh World Health Organization (WHO) pada kurun waktu 1959-1989 terhadap antropometri wanita masa hamil dan outcome kehamilan, menemukan beberapa informasi. Informasi itu adalah prevalensi BBLR berkisar antara 4,2 - 28,2 persen; kelahiran prematur 4,6 56 persen dan kegagalan pertumbuhan dalam uterus (IUGR) sebesar 5,8 - 54,2 persen. ${ }^{2)}$ Data proporsi BBLR di Indonesia diperoleh berdasarkan estimasi yang sifatnya sangat kasar. Dari Survei Demografi dan Kesehatan Indonesia (SDKI), proporsi BBLR yaitu antara 7-16persen selama periode 1986-1999 dan dari beberapa studi yang prevalensinya bervariasi, menunjukkan angka BBLR antara 10 -16persen. Jika proporsi ibu hamil yang akan melahirkan bayi adalah 2,5 persen dari penduduk maka setiap tahun diperkirakan 355.000 sampai 568.000 dari 5 juta bayi lahir mengalami kondisi BBLR. ${ }^{3)}$

Banyak faktor yang mempengaruhi berat lahir bayi, antara lain jenis kelamin bayi, ras, keadaan plasenta, umur ibu, aktivitas ibu, kebiasaan merokok, paritas, jarak kelahiran, tinggi badan dan berat badan ibu sebelum kehamilan, status sosial ekonomi, gizi, pemanfaatan pelayanan kesehatan dan pertambahan berat badan ibu selama kehamilan. Namun hubungan antara status gizi ibu dan berat lahir dalam kelangsungan hidup anak, yang telah konsisten menunjukkan hubungan dengan berat lahir, adalah 1) ukuran tubuh ibu, yaitu tinggi dan berat ibu sebelum hamil, dan 2) pertambahan berat ibu selama kehamilannya. ${ }^{4)}$

Studi di Purworejo Jawa Tengah yang mengikuti pola pertambahan berat badan dari sebelum hamil hingga melahirkan, memperoleh data sebesar 16,7 persen Wanita Usia Subur (WUS) menderita Kurang Energi Kronik (KEK). Sedang rata-rata pertambahan berat selama hamil adalah 8,3 $\pm 3,6 \mathrm{~kg}$, dan sebesar 79 persen tidak memenuhi rekomendasi pertambahan berat ibu hamil. Total pertambahan berat ini berhubungan dengan Indeks Massa Tubuh
(IMT) pra hamil, pendidikan, dan status sosial ekonomi. ${ }^{5)}$

Sementara itu studi di Kabupaten Indramayu, Jawa Barat mengenai hubungan status gizi ibu dan pertambahan berat badan selama kehamilan dengan berat dan panjang bayi yang dilahirkan, menunjukkan sebanyak 18 persen wanita hamil mempunyai berat badan pra hamil kurang dari $40 \mathrm{~kg}$ dan ratarata pertambahan berat kehamilan kurang dari $9 \mathrm{~kg}$. Perbandingan perkiraan pertambahan berat dengan jumlah pertambahan berat yang dibutuhkan untuk kompensasi berat pra hamil adalah rendah yaitu hanya 9 persen wanita hamil yang adekuat, dan kecukupan ini hanya dapat diberikan dari ibu yang berat badan pra hamil-nya cukup. ${ }^{6)}$

Pertambahan berat badan selama kehamilan penting untuk wanita yang memulai kehamilannya dengan status gizi kurus. Apabila batas berat lahir untuk kriteria "baik" atau "normal" menurut Puffer dan Serano (1987) adalah 3000 gram, berapa besar pertambahan berat selama kehamilan harus dimiliki ibu hamil untuk dapat melahirkan bayi dengan berat lahir $\geq 3000$ gram.

Rekomendasi WHO untuk pertambahan berat bagi ibu yang sehat dan status gizi "baik" adalah 10 - $14 \mathrm{~kg}$ selama kehamilan, dengan rata-rata $12 \mathrm{~kg}$ supaya dapat meningkatkan kemungkinan untuk melahirkan bayi genap bulan dengan berat lahir $3,3 \mathrm{~kg}$ serta menurunkan risiko terjadinya komplikasi pada ibu dan bayi, ${ }^{7)}$ menjadi tantangan yang harus dihadapi bersama. Mengingat masih banyak ibu yang memasuki masa kehamilannya dengan status gizi KEK, serta dari beberapa hasil penelitian menunjukkan bahwa pertambahan berat badan selama hamil masih di bawah anjuran $(10 \mathrm{~kg})$.

Prevalensi wanita yang menderita KEK di Indonesia dapat dilihat sebagai berikut: pada WUS sebesar 16 persen (Surkesnas 2001), prevalensi ibu hamil KEK di Provinsi Jawa Barat sebesar 29,6 persen, dan prevalensi ibu hamil KEK di Kabupaten Bogor sebesar 27,6 persen. Sementara itu wilayah penelitian Kecamatan Sukaraja 
adalah kecamatan dengan jumlah ibu hamil terbesar ke 6 dari 30 kecamatan yang ada di Kabupaten Bogor. Sehubungan rekomendasi WHO di atas, maka penelitian ini dilakukan untuk mengetahui hubungan pertambahan berat badan selama hamil dengan berat lahir bayi di Kecamatan Sukaraja, Kabupaten Bogor.

Tujuan dari penelitian ini adalah untuk mengetahui hubungan pertambahan berat badan selama kehamilan terhadap berat lahir bayi serta mengetahui faktor-faktor apa saja yang mempengaruhi, dari faktor yang diamati yaitu ukuran tubuh ibu sebelum hamil, asupan energi dan protein ibu, faktor obstetrik ibu, faktor sosio demografi, dan jenis kelamin bayi di Kecamatan Sukaraja, Kabupaten Bogor tahun 2001-2003.

\section{BAHAN DAN CARA}

Desain penelitian ini adalah potong lintang (cross sectional). Variabel yang diteliti adalah pertambahan berat selama kehamilan, berat lahir bayi, ukuran tubuh ibu (berat badan dan tinggi badan) serta indeks masa tubuh sebelum hamil, asupan energi dan protein ibu, faktor obstetrik ibu (paritas dan jarak lahir), faktor sosio demografi (umur, pendidikan dan tingkat kemiskinan), serta jenis kelamin bayi.

Populasi dalam penelitian ini adalah seluruh ibu hamil yang tinggal di wilayah Kecamatan Sukaraja, Kabupaten Bogor, Propinsi Jawa Barat. Kriteria inklusi yaitu: ibu hamil dengan usia kehamilan sekurangkurangnya 12 minggu, melahirkan bayi sehat/tidak BBLR dan cukup bulan (kehamilan di atas 37 minggu) serta bersedia untuk mengikuti prosedur yang ditetapkan selama penelitian. Kriteria eksklusi ibu hamil menderita penyakit menahun seperti jantung, paru-paru dan diabetes mellitus, dan berat bayi lahir < 2500 gr. Besar sampel setelah dilakukan pengambilan data diperoleh sampel penelitian sebesar 270. Jumlah sampel tersebut memenuhi jumlah sampel minimal yaitu 95 .

Metode analisis data yang digunakan adalah ukuran distribusi frekuensi setiap variabel, untuk melihat gambaran karakteristik responden. Kai Kuadrat untuk melihat hubungan dua variabel, yaitu antara variabel terikat dan variabel bebas. Regresi Logistik Ganda model Faktor Risiko dengan tingkat kemaknaan 0.05 , sedangkan tahapan analisis yang digunakan adalah seleksi variabel kandidat model $(p<0.25)$, pengembangan model dasar, uji interaksi $(p<0.005)$ dan pengembangan model akhir dengan penilaian konfounding (selisih OR 10 persen).

\section{HASIL}

\section{Gambaran Karakteristik Sampel}

Hasil analisis menggambarkan bayi yang lahir dengan berat 2500-2999 gram sebanyak 129 dari 270 bayi atau 47.8persen. Rata-rata berat bayi lahir adalah sebesar 3015 gram dengan standar deviasi 314 gram. Sedangkan ibu dengan pertambahan berat badan selama kehamilan kurang $9 \mathrm{~kg}$ sebanyak 132 ibu dari 270 ibu atau 48,9 persen. Rata-rata pertambahan berat badan selama kehamilan sebesar 9,1 kg dengan standar deviasi 2,51 kg. Rata-rata asupan energi ibu sebesar 1501 Kkal. Angka ini hanya memenuhi 66 persen dari rata-rata kecukupan energi, terdapat 61,9 persen ibu (167 dari $270 \mathrm{ibu}$ ) dengan asupan energi kurang dari 70 persen Angka Kecukupan Gizi (AKG). Sementara itu sebagian besar $(95,9 \%)$ asupan protein ibu kurang dari 70persen AKG, rata-rata asupan protein sebesar 30,5 gram. Gambaran selengkapnya karakteristik 270 sampel disajikan dalam besarnya proporsi dan persentase berdasarkan masing-masing variabel seperti pada Tabel 1 berikut: 
Tabel 1

Karakteristik sampel berdasarkan masing-masing variabel

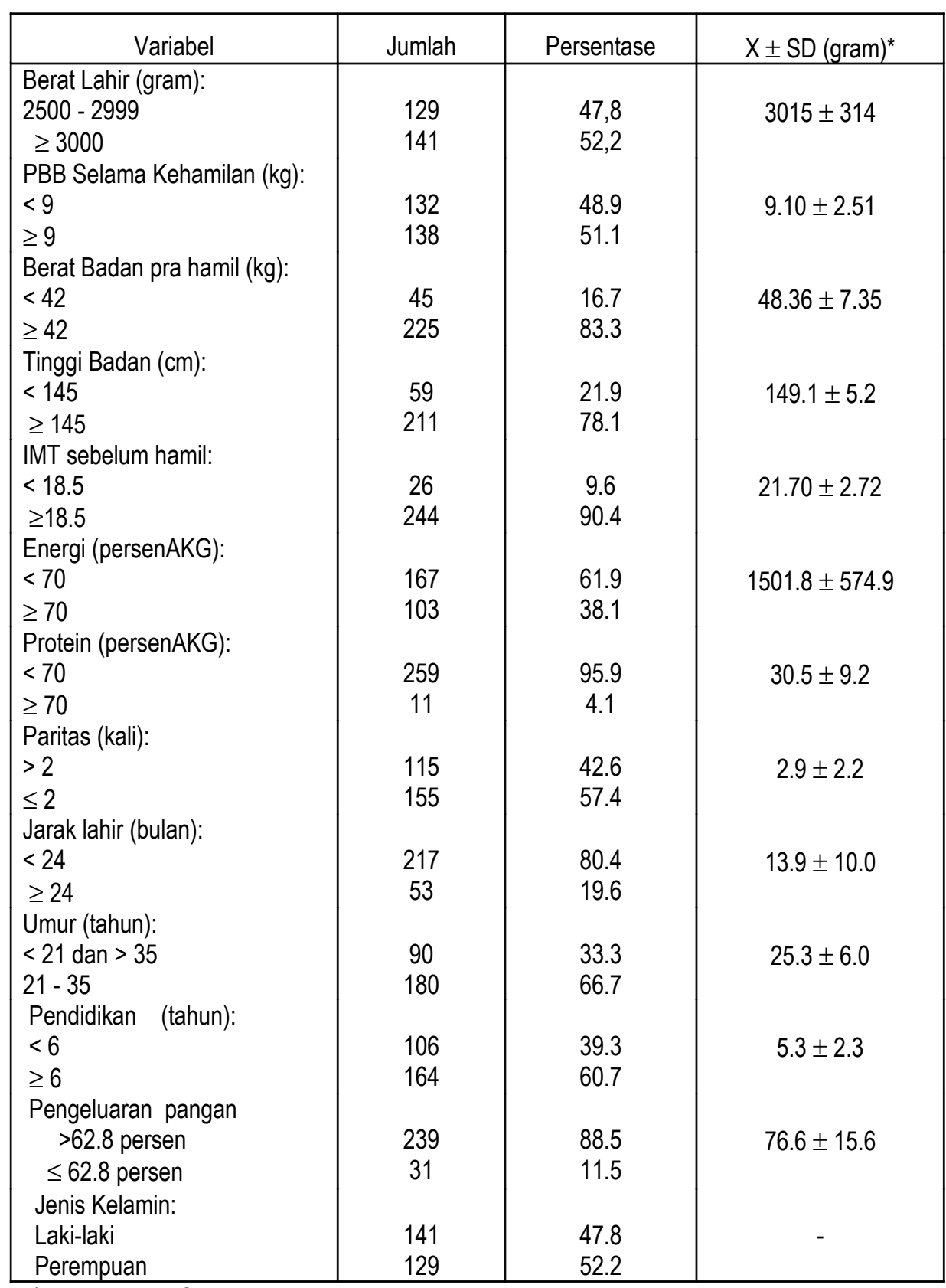

${ }^{*} \mathrm{X}=$ rata rata; $\mathrm{SD}=$ simpang baku 


\section{Hubungan Faktor yang Diamati dengan Berat Lahir Bayi}

Tabel 2

Hasil Uji Bivariat Pertambahan Berat Badan Selama Kehamilan dan seluruh Faktor Konfounding dengan Berat Lahir Bayi

\begin{tabular}{|c|c|c|c|c|c|c|c|}
\hline \multirow{3}{*}{ Variabel } & \multicolumn{4}{|c|}{ Berat lahir bayi (gr) } & \multirow{3}{*}{$O R^{* *}$} & \multirow{3}{*}{$95 \% \mathrm{Cl}^{* * *}$} & \multirow{3}{*}{$\begin{array}{l}\text { Nilai } \\
p^{\star \star * *}\end{array}$} \\
\hline & \multicolumn{2}{|c|}{$2500-2999$} & \multicolumn{2}{|c|}{$\geq 3000$} & & & \\
\hline & $\mathrm{n}^{*}$ & $\%$ & $\mathrm{n}$ & $\%$ & & & \\
\hline \multicolumn{8}{|l|}{$\begin{array}{l}\text { Pertambahan BB selama } \\
\text { kehamilan }\end{array}$} \\
\hline$<9 \mathrm{~kg}$ & 94 & 71.2 & 38 & 28.8 & 7.280 & $4.252-12.462$ & 0.000 \\
\hline$\geq 9 \mathrm{~kg}$ & 35 & 25.4 & 103 & 74.6 & & & \\
\hline \multicolumn{8}{|l|}{ Berat Badan sebelum hamil } \\
\hline $\begin{array}{l}<42 \mathrm{~kg} \\
\geq 42 \mathrm{~kg}\end{array}$ & $\begin{array}{r}19 \\
110\end{array}$ & 42.2 & $\begin{array}{r}26 \\
115\end{array}$ & $\begin{array}{l}57.8 \\
511\end{array}$ & 0.764 & $0.400-1.459$ & 0.513 \\
\hline \multicolumn{8}{|l|}{ Tinggi Badan } \\
\hline$<145 \mathrm{~cm}$ & 32 & 54.2 & 27 & 45.8 & 1.393 & $0.780-2.486$ & 0.329 \\
\hline$\geq 145 \mathrm{~cm}$ & 97 & 46.0 & 114 & 54.4 & & & \\
\hline \multicolumn{8}{|l|}{ Indeks Masa Tubuh (IMT) } \\
\hline$<18.5$ & 13 & 50.0 & 13 & 50.0 & 1.103 & $0.491-2.477$ & 0.974 \\
\hline$\geq 18.5$ & 116 & 47.5 & 128 & 52.5 & & & \\
\hline \multicolumn{8}{|l|}{ Asupan energi } \\
\hline$<70$ & 104 & 62.3 & 63 & 37.7 & 5.150 & $2.976-8.913$ & 0.000 \\
\hline$\geq 70$ & 25 & 24.3 & 78 & 75.7 & & & \\
\hline \multicolumn{8}{|l|}{ Asupan protein } \\
\hline$<70$ & 125 & 48.3 & 134 & 51.7 & 1.632 & $0.467-5.712$ & 0.641 \\
\hline$\geq 70$ & 4 & 36.4 & 7 & 63.6 & & & \\
\hline \multicolumn{8}{|l|}{ Paritas } \\
\hline$>2$ kali & 55 & 47.8 & 60 & 52.2 & 1.003 & $0.619-1.626$ & 1.000 \\
\hline$\leq 2$ kali & 74 & 47.7 & 81 & 52.3 & & & \\
\hline \multicolumn{8}{|l|}{ Jarak lahir } \\
\hline$<24$ bulan & 102 & 47.0 & 115 & 53.0 & 0.854 & $0.468-1.558$ & 0.718 \\
\hline$\geq 24$ bulan & 27 & 50.9 & 26 & 49.1 & & & \\
\hline \multicolumn{8}{|l|}{ Umur (tahun) } \\
\hline$<21$ dan $>35$ & 48 & 53.3 & 42 & 46.7 & 1.397 & $0.841-2.321$ & 0.245 \\
\hline $21-35$ & 81 & 45.0 & 99 & 55.0 & & & \\
\hline \multicolumn{8}{|l|}{ Pendidikan } \\
\hline Tidak tamat SD & 49 & 46.2 & 57 & 53.8 & 0.903 & $0.553-1.473$ & 0.775 \\
\hline Tamat SD & 80 & 48.8 & 84 & 51.2 & & & \\
\hline \multicolumn{8}{|l|}{ Proporsi Pengeluaran Pangan } \\
\hline$>62.8$ & 113 & 47.3 & 126 & 52.7 & 0.841 & $0.398-1.778$ & 0.792 \\
\hline$\leq 62.8$ & 16 & 51.6 & 15 & 48.4 & & & \\
\hline Jenis kelamin & & & & & & & \\
\hline Laki-laki & 65 & 46.1 & 76 & 53.9 & 0.889 & $0.538-1.401$ & 0.649 \\
\hline Perempuan & 64 & 49.6 & 65 & 50.4 & & & \\
\hline
\end{tabular}

${ }^{*}=$ jumlah sampel; ${ }^{* *}=$ Odd Ratio; ${ }^{* * *}=$ Confident interval ${ }^{* * * *}=$ tingkat kemaknaan

Pada tabel di atas terlihat proporsi bayi dengan berat kurang (2500-2999 gram) lebih tinggi pada ibu dengan pertambahan berat selama hamil kurang $9 \mathrm{~kg}(71,2 \%)$, tinggi badan ibu kurang $145 \mathrm{~cm}(54,2 \%)$, asupan energi kurang 70persen AKG (62,3\%), serta umur ibu kurang 21 tahun atau lebih dari 35 tahun $(53.3 \%)$. 


\section{Seleksi Variabel Kandidat}

Tabel 3

Hasil Seleksi Variabel Kandidat Model

\begin{tabular}{|l|c|c|c|c|c|}
\hline \multicolumn{1}{|c|}{ Variabel } & $\begin{array}{c}\text { Log- } \\
\text { Likelihood }\end{array}$ & G & Nilai $p$ & OR & $95 \% \mathrm{Cl}$ \\
\hline $\begin{array}{l}\text { Pertambahan BB } \\
\text { selama kehamilan }\end{array}$ & 314.757 & 59.009 & $\mathbf{0 . 0 0 0 ^ { 8 ) }}$ & 7.280 & $4.252-12.462$ \\
Berat badan sebelum & 373.095 & 0.617 & 0.413 & 0.764 & $0.400-1.459$ \\
hamil & & 1.262 & 0.261 & 1.393 & $0.780-2.486$ \\
Tinggi badan & 372.504 & 1.263 & \\
Indeks Massa Tubuh & 372.283 & 0.180 & 0.811 & 1.103 & $0.491-2.477$ \\
Asupan energi & 335.505 & 38.261 & $\mathbf{0 . 0 0 0 ^ { 8 ) }}$ & 5.150 & $2.976-8.913$ \\
Asupan protein & 373.158 & 0.608 & 0.436 & 1.632 & $0.467-5.712$ \\
Paritas & 373.766 & 0.000 & 0.989 & 1.003 & $0.619-1.626$ \\
Jarak lahir & 373.501 & 0.265 & 0.607 & 0.854 & $0.468-1.558$ \\
Umur & 372.096 & 1.670 & $\mathbf{0 . 1 9 6 ^ { 8 ) }}$ & 1.397 & $0.841-2.321$ \\
Pendidikan & 373.598 & 0.168 & 0.682 & 0.903 & $0.553-1.473$ \\
Pengeluaran untuk & 373.560 & 0.206 & 0.650 & 0.841 & $0.398-1.778$ \\
pangan & & & & & $0.538-1.401$ \\
Jenis kelamin bayi & 373.433 & 0.333 & 0.564 & 0.889 & 0.538 \\
\hline
\end{tabular}

${ }^{8)}$ masuk dalam tahapan multivariat $(p<0.25)$

Dari 12 variabel yang diamati ternyata hanya 3 variabel yang memenuhi kriteria nilai $p<0.25$. Tabel diatas hasil analisis bivariat dengan regresi logistik sederhana, terlihat konsisten dengan hasil analisis bivariat dengan Kai Kuadrat, yang mana hanya 3 variabel yang memenuhi kriteria $(p<0.25)$ yaitu pertambahan berat selama kehamilan, asupan energi serta umur. Ketiga variabel inilah yang masuk dalam analisis selanjutnya.

\section{Uji Interaksi}

Setelah diperoleh 3 variabel kandidat kemudian dilakukan identifikasi variabel interaksi. Interaksi atau modifikasi efek (effect modifier) adalah keanekaragaman (heterogenitas) dampak dari satu faktor risiko pada tingkat faktor risiko lain di populasi asal. Artinya suatu faktor risiko dapat memberikan dampak yang berbeda pada satu kelompok dengan kelompok lainnya. Jika tidak ada modifikasi efek, berarti dampak faktor risiko homogen. Apabila variabel-variabel saat bergabung menimbulkan dampak melebihi dari jumlah dampak masing-masing variabel, maka variabel-variabel tersebut dikatakan berinteraksi secara sinergis.

Selanjutnya dilakukan analisis secara bersamaan variabel utama, semua kandidat konfounding dan kandidat interaksi. Interaksi dibuat antara variabel utama yaitu pertambahan berat badan selama kehamilan dengan variabel kandidat.

Tabel 4

Hasil Analisis Multivariat Variabel Utama, Variabel Interaksi dengan Berat Bayi Lahir

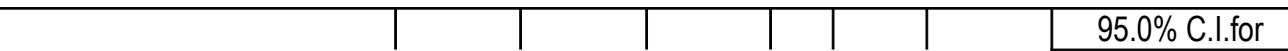




\begin{tabular}{|l|c|c|c|c|c|c|c|c|}
\hline \multicolumn{1}{|c|}{ Variabel } & B & S.E. & Wald & df & Sig. & Exp(B) & \multicolumn{2}{|c|}{ EXP(B) } \\
\cline { 6 - 9 } & & & & & & & Lower & Upper \\
\hline $\begin{array}{l}\text { Pertambahan Berat Badan } \\
\text { (PBB) }\end{array}$ & 1.810 & .547 & 10.936 & 1 & .001 & 6.111 & 2.090 & 17.866 \\
Umur & & & & & & & & \\
Asupan Energi & .738 & .436 & 2.864 & 1 & .091 & 2.092 & .890 & 4.918 \\
$\begin{array}{l}\text { PBB*Umur } \\
\text { PBB }{ }^{*} \text { Asupan Energi }\end{array}$ & -1.098 & .506 & .037 & 1 & .847 & 1.103 & .409 & 2.974 \\
Constant & 1.793 & 673 & 2.563 & 1 & .109 & .363 & .105 & 1.255 \\
& -1.431 & .383 & 13.059 & 1 & .008 & 6.010 & 1.601 & 22.566 \\
\hline
\end{tabular}

-2 Log Likelihood: 291.069 G:82.697 p=0.000

Dengan demikian pada analisis selanjutnya mengikutsertakan variabel asupan energi yang berinteraksi dengan pertambahan berat badan selama kehamilan (karena $p=0.009$ atau $p<0.05$ ), serta masing-masing variabel tersebut.

Tabel 5

Hasil Analisis Multivariat Variabel Utama, Variabel Interaksi dengan Berat Bayi Lahir (tanpa Interaksi Pertambahan BB*Umur)

\begin{tabular}{|c|c|c|c|c|c|c|c|c|}
\hline \multirow[b]{2}{*}{ Variabel } & \multirow[b]{2}{*}{ B } & \multirow[b]{2}{*}{ S.E. } & \multirow[b]{2}{*}{ Wald } & \multirow[b]{2}{*}{ df } & \multirow[b]{2}{*}{ Sig. } & \multirow[b]{2}{*}{$\operatorname{Exp}(B)$} & \multicolumn{2}{|c|}{ 95\% C.I.for EXP(B) } \\
\hline & & & & & & & Lower & Upper \\
\hline Pertambahan Berat Badan & 1,143 & 340 & 11,297 & 1 & ,001 & 3,135 & 1,610 & 6,104 \\
\hline Umur & ,262 & 301 &, 758 & 1 & ,384 & 1,300 &, 720 & 2,347 \\
\hline Asupan Energi & ,096 & ,501 & ,037 & 1 & 848 & 1,101 & ,412 & 2,940 \\
\hline PBB*Asupan Energi & 1,739 & 669 & 6,764 & 1 & ,009 & 5,691 & 1,535 & 21,103 \\
\hline Constant & $-1,097$ & 295 & 13,843 & 1 & ,000 & 334 & & \\
\hline
\end{tabular}

-2 Log Likelihood: 293,723 G:80.043 p=0,000

\section{Uji Variabel Konfounding / Pengganggu}

Setelah diperoleh variabel interaksi, selanjutnya dilakukan uji terhadap variabel yang diduga sebagai variabel konfounding. Uji variabel konfounding dilakukan pada variabel yang tidak berinteraksi, dengan kata lain apabila suatu variabel dinyatakan bermakna sebagai variabel interaksi pada saat uji interaksi, variabel tersebut tidak disertakan dalam uji konfounding. Analisis dilakukan dengan membandingkan nilai $\mathrm{OR}$ variabel utama pertambahan berat badan akhir kehamilan antara sebelum dan sesudah variabel konfounding dikeluarkan. Untuk menentukan konfounding digunakan indeks konfounding. Bila indeks lebih dari 10persen, maka variabel tersebut dikategorikan sebagai variabel konfounding. Bila variabel tersebut bukan variabel konfounding, maka dikeluarkan dari model.

Dalam analisis ini dilakukan uji konfounding pada variabel umur dan asupan energi. Namun karena asupan energi berinteraksi dengan pertambahan berat badan, walaupun variabel asupan energi mempunyai nilai $p>0.05$ tetap dimasukkan dalam analisis. Selanjutnya dikeluarkan variabel umur dan hasilnya seperti pada Tabel 6 .

Tabel 6

Hasil Analisis Multivariat Variabel Utama, Variabel Interaksi dengan Berat Lahir (tanpa Variabel Umur) 


\begin{tabular}{|c|c|c|c|c|c|c|c|c|}
\hline \multirow{2}{*}{ Variabel } & \multirow[t]{2}{*}{ B } & \multirow[t]{2}{*}{ S.E. } & \multirow[t]{2}{*}{ Wald } & \multirow[t]{2}{*}{ df } & \multirow{2}{*}{ Sig. } & \multirow{2}{*}{$\operatorname{Exp}(B)$} & \multicolumn{2}{|c|}{$\begin{array}{c}95.0 \% \text { C.l.for } \\
\operatorname{EXP}(B)\end{array}$} \\
\hline & & & & & & & Lower & Upper \\
\hline $\begin{array}{l}\text { Pertambahan Berat } \\
\text { Badan (PBB) }\end{array}$ & 1.130 & 339 & 11.131 & 1 & .001 & 3.097 & 1.594 & 6.016 \\
\hline Asupan Energi & .096 & .500 & .037 & 1 & .848 & 1.101 & .413 & 2.936 \\
\hline $\mathrm{PBB}^{*}$ Asupan Energi & 1.762 & 667 & 6.970 & 1 & .008 & 5.823 & 1.574 & 21.536 \\
\hline Constant & -.923 & .212 & 18.887 & 1 & .000 & .397 & & \\
\hline
\end{tabular}

-2 Log Likelihood: 294.484 G:79.282 $p=0.000$

Rasio OR variabel utama pertambahan berat badan setelah dilakukan uji konfounding adalah: (3.135 - 3.097)/3.097 X $100 \%=1.23 \%$, berarti kurang $10 \%$, maka variabel umur bukan konfounder.

\section{Hasil Akhir dan Interpretasi}

Tabel 5. di atas adalah merupakan hasil akhir analisis multivariat faktor yang berhubungan dengan berat lahir bayi. Berdasarkan hasil tersebut dapat dijelaskan bahwa interaksi antara ibu yang memiliki asupan energi kurang 70persen AKG dan pertambahan berat badan selama kehamilan kurang $9 \mathrm{~kg}$ berisiko 5,8 kali melahirkan berat bayi 2500-2999 gram dibanding pada ibu yang memiliki asupan energi lebih besar atau sama dengan 70persen AKG dan pertambahan berat badan selama kehamilan lebih atau sama dengan $9 \mathrm{~kg}$.

\section{BAHASAN}

Pertambahan Berat Badan Selama Kehamilan dan Hubungannya dengan Berat Lahir Bayi

Rata-rata pertambahan berat selama kehamilan pada penelitian ini sebesar 9,10 $\mathrm{kg}$. Hasil ini berbeda atau lebih tinggi dibanding penelitian Husaini $(1985){ }^{8)}$ di wilayah Bogor yaitu sebesar $8,8 \mathrm{~kg}$. Penelitian di berbagai wilayah Indonesia dilaporkan pertambahan berat selama kehamilan sebesar 6,8 kg di Madura ${ }^{10)}, 8,94$ $\mathrm{kg}$ di Indramayu ${ }^{6)}$, di Sliyeg dan Gabus Wetan Indramayu rata-rata pertambahan berat badan selama kehamilan hanya $7,5 \mathrm{~kg}$ 11), dan di Purworeja $8,4 \mathrm{~kg}^{5}$,. Studi Durnin
(1987 dalam Achadi, E. 2005) di 5 negara yaitu Skotlandia, Belanda, Thailand, Pilipina dan Gambia melaporkan rata-rata pertambahan berat badan selama hamil berturut-turut sebesar $11,5 \mathrm{~kg}, 10,5 \mathrm{~kg}, 8,9$ $\mathrm{kg}, 8,5 \mathrm{~kg}$, dan $7,6 \mathrm{~kg}$.

Hubungan pertambahan berat badan selama kehamilan dan berat lahir bayi pada penelitian ini dengan uji Kai Kuadrat bermakna secara statistik $p=0,000$ nilai $O R$ $=7,280(95 \% \mathrm{Cl} ; 4,252$ - 12,462). Perbedaan proporsi juga berbeda bermakna, terdapat 94 bayi dari $132(71,2 \%)$ bayi yang berat lahirnya 2500-2999 gram dari ibu yang pertambahan beratnya kurang $9 \mathrm{~kg}$. Sedangkan di antara ibu yang pertambahan beratnya lebih besar atau sama dengan $9 \mathrm{~kg}$ hanya ada 35 bayi dari $138(25,4 \%)$ bayi dengan berat lahir 2500-2999 gram.

Pada beberapa studi, ibu-ibu yang kurus atau kurang energi kronis saat pra hamil, kenaikan berat badan yang dimiliki selama kehamilan akan berpengaruh terhadap berat lahir bayi. Studi yang menghubungkan pertambahan berat badan selama kehamilan dan outcome kehamilan oleh Kramer, dalam meta analisisnya (yang dipublikasikan tahun 1976-1984), menemukan efek kausal dari pertambahan berat badan pada ibu hamil dengan IUGR sudah sangat mapan dan sensitif terhadap modifikasi. Alisjahbana ${ }^{12)}$ dalam studinya menemukan hubungan berat kehamilan pada minggu ke-34 kehamilan kurang dari 50 $\mathrm{kg}$ melahirkan bayi dengan berat kurang dari 3000 gram.

Studi menemukan perbedaan bermakna antara rata-rata berat bayi yaitu 3096 gram pada ibu hamil dengan pertambahan berat kurang $9 \mathrm{~kg}$ dengan rata-rata berat bayi 3215 
gram pada ibu hamil dengan pertambahan berat lebih besar atau sama dengan $9 \mathrm{~kg}$, perbedaan 119 gram bermakna secara statistik ( $p=0.037)^{10)}$. Demikian pula pada penelitian ini dalam hasil analisis uji $t$ (lampiran 2 dan 3) diperoleh perbedaan bermakna secara statistik $(p=0.000)$, antara rata-rata berat lahir bayi 2824 gram pada ibu hamil yang memiliki pertambahan berat kurang $9 \mathrm{~kg}$ dengan rata-rata berat lahir 3197 gram pada ibu hamil yang memiliki pertambahan berat lebih besar atau sama dengan $9 \mathrm{~kg}$.

\section{Faktor yang Mempengaruhi Hubungan Pertambahan Berat Badan Selama Kehamilan dengan Berat Lahir Bayi}

Analisis yang digunakan dalam penelitian ini adalah analisis Regresi, analisis ini hanya dapat menganalisis pengaruh langsung, dan tidak dapat menganalisis pengaruh tidak langsung (berbeda dengan analisis jalur). Namun dengan tahap uji interaksi dan konfounding dalam analisis Multivariat Regresi Logistik Ganda setidaknya diketahui asosiasi variabel kovariat dengan variabel utama dalam penelitian ini. Menurut Kardjati ${ }^{9)}$ status gizi ibu hamil selama kehamilan langsung berpengaruh terhadap pertumbuhan janin, sementara umur, paritas, jarak kelahiran dan yang lain berpengaruh terhadap pertumbuhan janin melalui ibu.

Hasil analisis bivariat dengan Kai Kuadrat maupun Regresi Logistik sederhana dari 12 variabel secara konsisten hanya ada 3 variabel yang secara statistik berhubungan dengan berat lahir yaitu pertambahan berat badan, umur dan asupan energi. Namun setelah dilakukan analisis multivariat hanya pertambahan berat badan sebelum hamil dan asupan energi yang berhubungan dengan berat lahir, terdapat interaksi antara asupan energi dengan pertambahan berat badan.

Hasil analisis Regresi Logistik Sederhana dalam penelitian ini menemukan bahwa pertambahan berat badan selama hamil secara tersendiri mempunyai pengaruh cukup besar, analisis secara statistik $p=$ 0,000 nilai $\mathrm{OR}=7,28$, berarti ibu hamil yang pertambahan memiliki berat selama kehamilan kurang $9 \mathrm{~kg}$ mempunyai risiko 7 kali melahirkan bayi dengan berat lahir kurang (2500-2999 gram). Namun dalam analisis multivariat terjadi interaksi antara asupan energi dengan pertambahan berat badan. Setelah dikoreksi dengan asupan energi dan interaksinya dengan pertambahan berat badan, pertambahan berat badan kurang $9 \mathrm{~kg}$ selama kehamilan berisiko 3 kali melahirkan bayi dengan berat 2500 -2999 gram. Risiko tersebut meningkat menjadi 5,8 kali pada ibu yang pertambahan beratnya selama kehamilan kurang $9 \mathrm{~kg}$ serta asupan energinya kurang 70persen AKG.

Penelitian Achadi ${ }^{6}$ menemukan hubungan konsumsi tablet besi 2 kali seminggu dan pertambahan berat badan yang cukup dengan berat bayi, sedangkan prediktor yang secara statistik bermakna terhadap perkiraan kecukupan pertambahan berat badan, yaitu IMT, umur ibu, pendidikan ibu, dan kepemilikan sepeda motor ( $n=447$, analisis Regresi Logistik). Demikian pula penelitian Winkvist ${ }^{5)}$ menemukan hubungan total pertambahan berat dengan IMT pra hamil, pendidikan dan status sosial ekonomi ( $n=251$, analisis MlwiN 1.02).

Penelitian ini mempunyai kesamaan dengan penelitian di New York City yang mengemukakan bahwa konsumsi energi berkorelasi positif dengan kenaikan berat badan selama kehamilan dan berat lahir bayi. Hasil penelitian di Aberdeen juga menemukan bahwa konsumsi energi berhubungan erat dengan berat lahir, demikian pula tinggi badan ibu dengan berat lahir. Disimpulkan dalam penelitian ini ibu hamil yang berbadan tinggi dan besar serta mengkonsumsi energi yang banyak, akan melahirkan bayi yang lebih besar ${ }^{9}$ ).

Pada masyarakat mampu, hubungan konsumsi energi dan berat lahir bayi tidak tampak nyata. Terlebih ibu yang gemuk, walaupun konsumsi energi dikurangi, berat bayi lahir tetap normal. Hubungan asupan energi dan berat lahir dapat tampak nyata pada keluarga ekonomi rendah Asupan energi mempunyai pengaruh yang besar pada kenaikan berat badan dan berat lahir 
pada masyarakat yang kurang mampu dan ibu yang kurus sebelum hamil ${ }^{8)}$. Hal tersebut tergambar dalam penelitian ini, dari data univariat diketahui bahwa sebagian besar $(88.55 \%)$ dengan proporsi pengeluaran untuk pangan lebih besar 62,8 persen, yang menurut BPS/UNDP berarti termasuk dalam kategori miskin. Demikian pula bila dilihat dari status gizi pra hamil masih terdapat ibu menderita KEK, yaitu 16,7 persen atau 45 ibu yang mempunyai berat badan kurang 42 $\mathrm{kg}$ dan 9.6 persen atau 26 ibu dengan IMT kurang 18,5.

Rata-rata asupan energi per hari pada penelitian ini hanya memenuhi 66 persen dari kecukupan energi ibu hamil yaitu 2270 kkal. Rata-rata asupan energi sebesar 1501 kkal. Rata-rata asupan energi ini sama dengan rata-rata asupan energi pada penelitian di Sampang Madura yaitu 1500 $\mathrm{kkal}^{10)}$, sementara itu penelitian lain menunjukkan rata-rata asupan energi yang lebih tinggi yaitu 1579 kkall $^{11)}$. Hasil analisis dengan menggunakan uji perbedaan ratarata, diperoleh ibu yang melahirkan bayi dengan berat lahir $\geq 3000$ gram rata-rata mengkonsumsi energi sebesar 1718 kkal. Rata-rata ini lebih besar (perbedaan bermakna $p=0.000$ ) dibanding konsumsi energi dari ibu yang melahirkan bayi dengan berat 2500-2999 gram yaitu sebesar 1266 kkal.

Hasil analisis bivariat diperoleh hubungan yang bermakna antara asupan energi ibu dengan berat bayi lahir dalam penelitian ini. Dari analisis diperoleh nilai OR $=5,150$, artinya ibu yang konsumsi energinya kurang dari 70persen AKG mempunyai risiko 5 kali melahirkan bayi dengan berat 2500 - 2999 gr. Hasil ini berbeda dengan temuan penelitian Mutiara (2006), yang menunjukkan tidak ada hubungan bermakna antara asupan energi selama kehamilan dengan berat bayi lahir.

Rata-rata asupan protein sebesar 30,5 gram, rata-rata ini hanya memenuhi 45,5persen terhadap AKG yang dianjurkan untuk ibu hamil yaitu sebesar 67 gram. Rata-rata asupan energi ini lebih rendah dari rata-rata asupan protein penelitian Kardjati (1986) di Sampang yaitu 41 gram. Meskipun tidak terdapat perbedaan proporsi kejadian bayi lahir 2500 - 2999 gr antara ibu dengan asupan protein ibu selama hamil kurang 70 persen dengan asupan protein ibu lebih besar sama dengan 70 persen, terdapat kecenderungan bahwa rata-rata berat lahir bayi dari ibu yang mengkonsumsi protein lebih besar 70 persen AKG lebih berat (3168 gram dibanding 3008 gram, $p=0.099$ ). Hubungan asupan protein dengan berat lahir yang tidak bermakna juga ditemukan pada penelitian Kardjati ${ }^{10}$.

Penelitian ini menunjukkan terdapat kecenderungan bahwa ibu hamil dengan umur $<20$ tahun dan $>35$ tahun melahirkan bayi yang lebih kecil (rata-rata 2995 gram) dibanding berat lahir bayi pada ibu yang berumur 21-35 tahun (rata-rata 3024 gram). Pengaruh umur terhadap berat lahir menurut hasil penelitian Thai Nguyen di Vietnam (2003 dalam Mutiara, 2006) menunjukkan bahwa risiko BBLR pada ibu hamil kurang 20 tahun sebesar 1,4 kali lebih besar dibanding ibu hamil 20-34 tahun. Demikian pula risiko BBLR pada ibu hamil $\geq 35$ tahun sebesar 1,8 kali lebih besar dibanding ibu hamil 20-34 tahun. Penelitian Mutiara di Indramayu tahun 2001-2002 menunjukkan adanya hubungan bermakna antara umur dan berat lahir $(p=$ $0,043)$ meskipun kekuatan hubungan tersebut lemah $(r=0,139)$, namun pengaruh tersebut menunjukkan mengikuti fenomena huruf $U$ terbalik, artinya pada umur yang muda (kurang dari 20 tahun) dan tua (lebih besar 35 tahun) berat bayi yang dilahirkan cenderung lebih kecil daripada umur 21 -35 tahun.

\section{KESIMPULAN}

Proporsi bayi lahir dengan berat badan 2500-2999 gram adalah 47,8persen (129 bayi) dan bayi lahir dengan berat lebih besar sama dengan 3000 gram sebesar 52,2persen (141 bayi). Rata-rata berat lahir adalah 3015 gram. Proporsi ibu dengan pertambahan berat badan selama kehamilan kurang $9 \mathrm{~kg}$ sebanyak 48,9 persen (132 ibu) dan ibu dengan pertambahan berat badan 
selama kehamilan lebih besar sama dengan $9 \mathrm{~kg}$ sebanyak 51,1 persen (138 ibu). Ratarata pertambahan berat badan selama kehamilan sebesar $9,10 \mathrm{~kg}$

Faktor yang berhubungan dengan berat lahir bayi adalah pertambahan berat badan. Asupan energi berinteraksi dengan pertambahan berat badan selama kehamilan dan memberikan nilai OR terhadap berat lahir sebesar 5,8. Dari hasil interaksi pertambahan berat badan selama kehamilan dengan asupan energi tersebut dapat dinyatakan ibu dengan asupan energi kurang 70persen AKG dan memiliki pertambahan berat badan selama kehamilan kurang $9 \mathrm{~kg}$ berisiko 5,8 kali melahirkan bayi dengan berat 2500-2999 gram dibanding ibu dengan asupan energi lebih besar sama dengan 70 persen AKG dan memiliki pertambahan berat badan selama kehamilan leboh besar $9 \mathrm{~kg}$.

lbu yang melahirkan bayi dengan berat lebih besar sama dengan 3000 gram memiliki rata-rata konsumsi energi lebih besar dari pada ibu yang melahirkan bayi dengan berat 2500-2999 gram, yaitu sebesar 1718 kkal. lbu yang melahirkan bayi dengan berat lahir bayi 2500-2999 gram memiliki rata-rata konsumsi energi lebih kecil dari pada ibu yang melahirkan bayi dengan berat leboh besar sama dengan 3000 gr, yaitu 1266 sebesar kkal.

\section{SARAN}

Perlu dimasyarakatkan anjuran pertambahan berat badan selama kehamilan sekurang-kurangnya $9 \mathrm{~kg}$ untuk memperoleh berat lahir bayi leboh besar sama dengan 3000 gram. Untuk mencapai pertambahan berat badan selama kehamilan minimal $9 \mathrm{~kg}$ perlu disertai asupan energi lebih besar 70 persen AKG. Anjuran ini ditujukan untuk ibu hamil yang kurus atau normal pada saat pra hamil. Perlu ditingkatan penyuluhan mengenai pentingnya menimbang berat badan serta konsumsi energi, protein dan zat gizi lain yang adekuat sejak merencanakan kehamilan dan selama kehamilan, oleh dokter, bidan, dan perawat atau petugas kesehatan lainnya. Perlu dilakukan intervensi oleh pemerintah melalui pemberian suplementasi gizi dan pemberian makanan tambahan untuk ibu hamil dengan risiko tinggi perlu diberikan sejak awal kehamilan untuk mencapai pertambahan berat minimal $9 \mathrm{~kg}$ pada akhir kehamilan

Perlu diadakan penelitian dengan desain tersendiri (misalnya, kohor) dimulai dengan berat badan pra hamil sampai dengan melahirkan, untuk wilayah yang berbeda (perkotaan) dan heterogen risiko atau konsekuensi penggunaan cut-off point 2500 gram untuk berat lahir rendah dan 3000 gram untuk berat lahir kurang. Penelitian ini sebagai masukan untuk menetapkan cut-off point berat lahir bayi yang berisiko, khususnya terhadap kualitas pertumbuhan dan perkembangan, dan tidak hanya untuk ketahanan hidup anak saja. Lebih jauh lagi terhadap predisposisi obesitas, penyakit jantung, hipertensi, dan Diabetes Mellitus tipe II.

\section{RUJUKAN}

1. Puffer,RR dan Serano,CV., "Patterns of Birthweights", Scientific Publication No.504, Pan American Health Organization, World Health Organization, Washington, 1987

2. WHO Expert Commitee, Physical Status: The Use And Interpretation of Anthropometry, Switzerland: World Health Organization, 1995

3. Atmarita dan Fallah, Tatang, S., "Analisis Situasi Gizi dan Kesehatan Masyarakat" dalam Prosiding Widya Karya Nasional Pangan dan Gizi VIII, 17-19 Mei 2004, Jakarta: LIPI, 2004

4. Worthington, Bonnie, S. and Williams, Sue, R. "Nutrition Throughout the Live Cycle", McGraw-Hill Higher Education, 2000

5. Winkvist, Anna, et.al. "Weight-Gain Patterns From Prepregnancy until Delivery Among Women in Central Java, Indonesia" Am J Clin Nutr, Volume 75 , No. 6 , 2002: 1072-1077 
6. Achadi, E.L, et.al. "Woman's Nutritional Status, Iron Consumption and Weight Gain During Pregnancy in Relation to Neonatal Weight and Length in West Java, Indonesia". International Journal of Gynocology \& Obstetrics, 48 Suppl. (1995) S103-S119.

$7 . \quad$ _ Draft: "Antropometri lbu Hamil dan Ibu Menyusui" Jakarta: unpublished, 2005

8. Husaini, Y.K., et.al. 'Kartu Menuju Sehat (KMS) Ibu Hamil: Teknologi Sederhana Untuk Menunjang Program Kesehatan' dalam'Hasil Seminar IPTEK Gizi dan Kesehatan Ibu Hamil' Kerjasana Unair, Puslitbang Gizi Depkes RI, Royal Tropical Institute. Cipanas, 14-15 Oktober 1986

9. Husaini, M.A., dan Y.K Husaini, 'Keadaan Gizi, Makanan Tambahan dan Hasil Kehamilan' dalam 'Hasil Seminar IPTEK Gizi dan Kesehatan Ibu Hamil' Kerjasana Unair, Puslitbang Gizi
Depkes RI, Royal Tropical Institute. Cipanas, 14-15 Oktober 1986

10. Kardjati, Sri., J.A. Kusin, dan C. de With 'Factors Influencing Birthweight" dalam "Hasil Seminar IPTEK Gizi dan Kesehatan Ibu Hamil' Kerjasana Unair, Puslitbang Gizi Depkes RI, Royal Tropical Institute. Cipanas, 14-15 Oktober 1986

11. Mutiara, Erna. 'Pengaruh Aktivitas Fisik Selama Kehamilan Terhadap Berat Lahir: Suatu Kohort Prospektif Di Indramayu, Jawa Barat”.2006. Disertasi Program Doktor IImu Kesehatan Masyarakat, Program Pascasarjana, FKM UI

12. Alisjahbana, Anna, Dewi H. Utama dan R.Peeters. 'Maternal Nutritional Variables and Pregnancy Outcome' dalam 'Hasil Seminar IPTEK Gizi dan Kesehatan Ibu Hamil' Kerjasana Unair, Puslitbang Gizi Depkes RI, Royal Tropical Institute. Cipanas, 14-15 Oktober 1986 